\title{
Second MRSA outbreak in a nursing home; role for a super spreader or super sensitive resident
}

\author{
P Gruteke ${ }^{1 *}$, A Haenen $^{2}$, M Scholing ${ }^{1}$, C van Teunenbroek ${ }^{3}$, A de Neeling ${ }^{2}$ \\ From International Conference on Prevention \& Infection Control (ICPIC 2011) \\ Geneva, Switzerland. 29 June - 2 July 2011
}

\section{Introduction / objectives}

MRSA prevalence is low in nursing homes (NH) in the Netherlands. However, outbreaks in $\mathrm{NH}$ are usually larger than those occurring in hospitals. The national MRSA database shows that in the last three years $24 \%$ of the outbreaks occurred in $\mathrm{NH}$. The $\mathrm{NH}$ under investigation experienced outbreaks in 2007 and 2010. Two residents and one health care worker (HCW) were involved in both outbreaks. One of these residents ( $\mathrm{R}-\mathrm{Z})$ has diabetes and pressure ulcers, and wasÂt therefore not considered for eradication therapy. $\mathrm{R}-\mathrm{Z}$ could have acted as a super spreader.

\section{Methods}

Laboratory records and outbreak courses were studied for the role of R-Z in both outbreaks.

\section{Results}

The first outbreak (MRSA spa t032) was noted when two residents were admitted to the nearby hospital, and gave rise to spread to two hospital patients and two nurses. 12 $\mathrm{NH}$ residents and $4 \mathrm{NH}-\mathrm{HCW}$ s were found colonized. The second outbreak (MRSA spa t539) was noted in the OPD of the hospital without further colonization's in the hospital. $11 \mathrm{NH}$ residents and $5 \mathrm{NH}-\mathrm{HCW}$ sere colonized in the second episode. During 2009 and early 2010 $\mathrm{R}-\mathrm{Z}$ had been tested negative for MRSA on 7 occasions. Precaution measures instituted in 2007, were lifted. A positive MRSA result in May 2010 was initially mistaken as a recurrence, and neighboring residents and attending HCWs wereÂ screened negative. Only after the outbreak was noted 2 months later, typing revealed colonization with a new strain.

${ }^{1}$ OLVG, Amsterdam, Netherlands

Full list of author information is available at the end of the article

\section{Conclusion}

We cannot conclude that persistent super spreading occurred, since R-Z eventually cleared the MRSA. The fact that $R-Z$ was the first to get colonized with the new strain illustrates increased susceptibility. Colonizationprone patients may require life long protective measures and surveillance.

\section{Disclosure of interest}

None declared.

\section{Author details}

${ }^{1} \mathrm{OLVG}$, Amsterdam, Netherlands. ${ }^{2}$ RIVM, Bilthoven, Netherlands. ${ }^{3}$ Zorggroep, Almere, Netherlands.

Published: 29 June 2011

doi:10.1186/1753-6561-5-S6-P162

Cite this article as: Gruteke et al: Second MRSA outbreak in a nursing home; role for a super spreader or super sensitive resident. BMC Proceedings 2011 5(Suppl 6):P162.

Submit your next manuscript to BioMed Central and take full advantage of:

- Convenient online submission

- Thorough peer review

- No space constraints or color figure charges

- Immediate publication on acceptance

- Inclusion in PubMed, CAS, Scopus and Google Scholar

- Research which is freely available for redistribution 